\title{
High School Students' Perceptions of and Attitudes towards Teacher Power in the Classroom
}

\author{
Konstantina Koutrouba ${ }^{1}$, Eleni Baxevanou ${ }^{2} \&$ Athanasios Koutroumpas $^{2}$ \\ ${ }^{1}$ Assistant Professor in Teaching Studies, Harokopio University, Department of Home Economics and Ecology, \\ Athens, Greece \\ ${ }^{2}$ High school teacher, Department of Home Economics and Ecology, Athens, Greece \\ Correspondence: Konstantina Koutrouba, Assistant Professor in Teaching Studies, Harokopio University, \\ Department of Home Economics and Ecology, 70 El. Venizelou Str. 17671 Athens, Greece. E-mal: \\ kkout@hua.gr
}

Received: June 11, 2012

Accepted: June 22, 2012 Online Published: August 27, 2012

doi:10.5539/ies.v5n5p185

URL: http://dx.doi.org/10.5539/ies.v5n5p185

\begin{abstract}
The present study examines Greek High School students' perceptions of and attitudes towards their teachers' power, from findings produced during a questionnaire-based study conducted in the period 2010-2011, with the participation of 1076 students attending 68 schools across Greece. Greek students provided information on how their teachers exert didactic and legitimate power in the classroom and on how students themselves react whenever their teachers abuse power. Data elaboration, statistical and factor analysis showed that, according to students, teachers exert didactic power mainly by exhibiting profound knowledge and applying effective teaching and assessment methods, while they exert legitimate power through implementing rules, inflicting punishment and controlling students' behaviour. The study also showed that students react passively to power abuse due to fear of possible consequences, aggressively when a teacher's power is regarded as excessively unfair, or positively when relations of trust and acceptance have been established between the teacher and the student.
\end{abstract}

Keywords: teacher power, students' perceptions, secondary education, Greece

\section{Introduction}

The review of international literature referring to 'teacher power' within the school setting reveals that notion and connotations of the term have progressively changed through time. Initially and traditionally, teacher power simply denoted teachers' academic or behavioural demands which students should passively and without any objection obey to (Petersm, 1966; Metz, 1978; Kearney, Plax, Richmond, \& McCroskey, 1984; Franklin, 1986). Richmond and McCroskey (1984) defined teacher power as teachers' capacity to influence their students to do something [i.e. to participate in the learning process] they would not have done had they not been influenced by the teacher. Consequently, according to these researchers, if a teacher does not exert power in a classroom, that teacher cannot enhance students' learning outcomes and, therefore, s/he cannot be described as an effective professional.

Today, 'teacher power' is specified mainly as a combination of 'didactic' and 'legitimate' power. According to Harjunen (2009), didactic is the power teachers exert on their students based on profoundly assimilated knowledge of the subject content and of teaching tactics that facilitate effective knowledge dissemination. According to McCroskey and Richmond (1983), legitimate power is the right teachers have to make certain demands and requests as a function of their position as teachers. More specifically, teachers have the statutory or customary right to set behavioural rules, inflict punishments, establish rules and principles for student-teacher communication and create the pedagogical atmosphere in the classroom, developing, in this way, relations with the students on the basis of the teacher's personal criteria.

Defining further teacher power and its constituent elements McCroskey and Richmond (1983) remarked that the ways teachers communicate with their students to a large extent determines the type and the extent of the power they exert over those students, while the same researchers added that teacher power exists only in so far as students perceive it to exist and accept it (Richmond \& McCroskey, 1984). This acceptance was described by 
van Manen (1991) as a major constituent element of teacher power which 'is granted by the child, first on the basis of his/her trust and love, and later on the basis of critical understanding'. Pace and Hemmings (2007) reported that in the real world of classrooms, teacher power is enacted through on-going negotiations between teachers and students and often involves conflict that affects the balance of legitimacy and consent. Finally, Harjunen (2011) confirmed that teacher power is based on a combination of interactions between teacher and students in the classroom where enduring tension between positive and negative aspects of teacher power is displayed. She also reported that for teachers who effectively exert their power 'the goal is to find ways to get students to participate in the teaching-studying-learning process' (Harjunen, 2011).

The above mentioned remarks imply that during the learning/teaching process, beyond the power exerted by the teacher over the students, the influential reactionary power exerted by the students impacts the teacher's control strategies (Baringer \& McCroskey 2000; Harjunen, 2011; Levinem \& Wheeless, 1997; Mottet, Beebe, Raffeld, \& Paylset, 2004). In fact, according to Golish's findings (1999), students tend to use various behavioural techniques and messages during the learning process in order to moderate their teacher's power. More specifically, in their effort to gain the teacher's understanding, students use both verbal and nonverbal strategies and, more rarely, when their more positive attempts have failed, display antisocial reactions. In addition, Gallagher (2008) found that students can exercise power by complying with, resisting, avoiding or reproducing the power exercised over them by their own teacher. Therefore, since student behaviour constitutes a reaction to teacher behaviour, daily communicative interaction between teacher and student depends, to a large extent, on the specific types of power that the teacher exerts upon his/her students.

It is, therefore, rather apparent that, as Yariv (2009) highlights, teacher power has its own boundaries, namely a red line beyond which some teacher attitudes are not acceptable to the students; teacher power is governed by legislation, governmental rules, school norms and, also, by the boundaries the principal, colleagues and pupils have set. Yariv, represents the boundaries of teacher power with a three-circled figure, where the inner circle indicates the most established and legitimate teacher duties and rights, the middle one refers to teacher practices that could be characterized by the students as arrogant, insensitive and abusive, while the external circle represents the world outside school, where the teacher power's red line lies; beyond this line the teacher has not any legitimate right to get involved. It has been also reported that, as regards adolescent students, teacher power boundaries become more unambiguous and blurred, since these students try to shake off their allegiance to adult power, becoming thus more impervious to their teacher's power (Coleman \& Zajicek-Coleman, 1984; Gregory \& Ripsky, 2008; Murray \& Thompson 1985; Smetana \& Bitz, 1996).

The type and the extent of the power exerted by teachers seem to be, thus, crucial for the accomplishment of the teaching/learning process. When teachers use their power (didactic or legitimate) in a coercive way based exclusively on the role assigned to the teacher by the State and on the threat of student punishment, student power is seemingly minimized due to each student's fear of being punished or becoming the black sheep of the classroom (Richmond \& Roach, 1992). However, this form of power exertion is considered to delay positive cognitive, affective and social learning outcomes, and activate instead smouldering discontent that may result in undesirable effects. In contrast, positive use of teacher power is considered to enhance learning effects (Lee, Levine, \& Cambra, 1997; Richmond \& McCroskey, 1984), especially cognitive and affective ones, as Ellis (2000) has shown. Turman and Schrodt (2006), defining 'positive use of power' have further shown that educators who exert positively their power in the classroom: (a) are interested in whether students are learning, (b) take time to answer students' questions fully, (c) believe students can do well in their class, (d) make efforts to get to know their students, and (e) use an interactive teaching style. These educators are more likely to be accepted by the students and are perceived as effectual when displaying their power while student reaction is minimized due to the feelings of mutual trust and respect that are generated.

\subsection{What about Greece?}

As far as Greece is concerned, research on relevant topics is quite limited, given that the Greek educational system, despite successive innovative reforms, remains rather conservative and bureaucratic; Curricula are regarded as inflexible as regards teachers' ability to implement individualized, attractive and alternative teaching strategies in order to facilitate constructive teaching and effectively enhance learning (Ifanti, 2007; Koustourakis, 2007). They also seem to be strictly orientated at accelerating academic performance and the quantitative increase of cognitive achievements, while affective and social objectives are apparently underestimated. Consequently, teachers could be regarded as standing on quicksand, since they are not provided with official professional assistance and support which could help them define successfully the boundaries of their power within the school setting, namely take full advantage of the positive aspects of their power, reduce unconstructive display of power and deactivate undesirable reactions by the students (Alahiotis \& Karatzia, 2006; 
Katsikas \& Therianos, 2008). The present study aims at examining Greek high school students' perceptions of their teachers' didactic and legitimate power in the classroom and their reactions in cases of power abuse.

\section{Methodology}

The present questionnaire-based research was conducted during the academic year 2010-2011. A group of 23 University students were provided by the researchers with systematic information in order to help high school students in different Greek areas to understand and then fill in a questionnaire comprising 41 close-ended questions. During a pilot phase questionnaires were completed by 30 Greek high school students, so that the researchers could make necessary improvements regarding the structure and the expression of items, to make the tool more 'friendly' to and comprehensible by school students. During the second phase the University students and the researchers visited 68 high schools throughout Greece and distributed in total 1300 questionnaires after making personal contact with school principals, teachers and students. These schools were selected on the basis of criteria regarding teacher and student population and socio-financial features of local communities in order to ensure that as many students as possible, living in varied social, economic and educational environments, would provide relevant information. More specifically, the catchment areas of the schools were divided into four categories (Low, Low/Medium, Upper/Medium, High) on the basis of their socio-economic characteristics using a property value indicator provided by the Ministry of Economics. Schools were then allocated to one of four categories: Seventeen schools were identified as serving areas of low socio-economic status, 17 as serving areas of low/medium socio-economic status, 17 were considered to serve areas of upper/medium and 17 areas of high socio-economic status. The ratios of the selected students to schools and of schools to each area represented the corresponding national ratios, ensuring, as far as possible, that the sample was representative, although the examination of the correlation between socio-financial features and students' perceptions of and attitudes towards teacher power belongs not to the aims of the present paper but to the aims of an ongoing forthcoming research.

The questionnaire comprised 40 close-ended questions with pre-coded replies: 5 of which required students to provide information about their personal profile and their academic background, while 36 questions and their pre-coded replies (which are presented as items/variables 1-36 in the following tables 1,2 and 3) referred to students' perceptions about and attitudes towards their teachers' didactic and legitimate power. The questionnaire, originally written in Greek and then translated in English for the purposes of this paper, was self-administered because it was not possible to indentify an instrument from the literature that allowed researchers to capture all the variables involved in this study. For this reason, the synthesis of the questionnaire was mainly based on the research findings of Harjunen (2011), Turman and Schrodt (2006) and Yariv (2009) who firstly defined the notion and connotations of didactic and legitimate power, and, secondly, described high school students' reactions to their teachers' abuse of power in the classroom.

One thousand and seventy six students $(\mathrm{n}=1076,54.9 \%$ girls, $45.1 \%$ boys) agreed to cooperate with the researchers and fill in the questionnaire (response rate: $82.7 \%$ ). The majority of the participants $(71 \%)$ were 12-14 years old (Lower High School students) while 29\% were 15-17 years old (Upper High School students). Moreover, the respondents' academic performance during the past school semester was assessed and described as follows: 'excellent' (32.2\%), 'very good' (39.5\%), 'good' (21.7\%), 'moderate' (6.1\%) and 'insufficient' $(0.5 \%)$. The examination, however, of the correlation between students' features, such as age (which Yariv (2009) found that statistically it was insignificant with regard to most aspects of teachers' authority, except in children's tendency to respond to unjust treatment), gender or grade level and students' perceptions of and attitude towards teacher power will be aims of the abovementioned ongoing research.

The scoring of the 36 questions referring to students' perceptions and attitudes was based on nominal five-point Likert-type scales (i.e. $1=$ not at all, $2=$ slightly, $3=$ =moderately, $4=$ much, $5=$ very much), incorporating properties of labelling and classification. A statistical coding of questions and answers followed the collection of the questionnaires. Data elaboration and statistical analysis were performed using PASW Statistics 18. Subsequently, factor analysis was used as an analytic technique that permits the reduction of a large number of present survey correlated variables to a smaller number of latent dimensions. The main goal of the using of factor analysis was to achieve parsimony by using the smallest number of explanatory concepts to explain the maximum amount of common variance in a correlation matrix (Tinsley \& Tinsley, 1987). More specifically, in this article, factor analysis was employed, using PCA with Varimax rotation extraction method, to pinpoint the main factors influencing the participants' views on their teachers' power in the classroom. All relevant statistical tests were performed at a significance level $\alpha=0.01$. A broad outline of the more significant results and conclusions of the present research is presented below. 


\subsection{Analysis of Results}

\subsubsection{Students' Perceptions and Attitudes}

Table 1. Students' perceptions (in percentages) to the questions looking at teacher's didactic power in the classroom

\begin{tabular}{|c|c|c|c|c|c|c|}
\hline & $\begin{array}{l}\text { Degree of consent to the following teacher's } \\
\text { traits/actions/attitudes regarding teacher's } \\
\text { didactic power. } \\
\text { I consent to the teacher when } \text { s/he: }\end{array}$ & 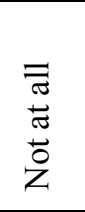 & 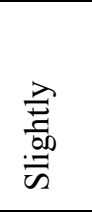 & $\begin{array}{l}\frac{\lambda}{0} \\
\frac{\pi}{\pi} \\
\frac{\overrightarrow{0}}{0} \\
\sum\end{array}$ & $\stackrel{\tilde{S}}{\Sigma}^{\frac{\pi}{\Sigma}}$ & $\begin{array}{l}\bar{̃} \\
\stackrel{0}{\Xi} \\
\overbrace{0}^{D} \\
>\end{array}$ \\
\hline 1 & $\begin{array}{l}\text { Has profound content-based knowledge of the } \\
\text { teaching subject }\end{array}$ & 0.6 & 1 & 6.1 & 31 & 61.3 \\
\hline 2 & $\begin{array}{l}\text { Checks students' prior knowledge before providing } \\
\text { new information }\end{array}$ & 2.9 & 5.6 & 12.6 & 47.8 & 31.1 \\
\hline 3 & $\begin{array}{l}\text { Utilizes simple and intelligible language when } \\
\text { teaching }\end{array}$ & 0.8 & 3.4 & 12.1 & 36.1 & 47.6 \\
\hline 4 & $\begin{array}{l}\text { Provides examples and paradigms to simplify } \\
\text { obscure terms/notions/facts }\end{array}$ & 0.6 & 3.1 & 17.5 & 40.2 & 38.7 \\
\hline 5 & $\begin{array}{l}\text { Utilizes learner-centred teaching strategies to } \\
\text { facilitate students' active participation in the } \\
\text { learning procedure }\end{array}$ & 1.7 & 4.3 & 14.5 & 39.3 & 40.2 \\
\hline 6 & $\begin{array}{l}\text { Prompts students to work in groups and carry out } \\
\text { learning projects }\end{array}$ & 1 & 3.2 & 13.4 & 28.9 & 53.5 \\
\hline 7 & $\begin{array}{l}\text { Provides frequent feedback during the teaching } \\
\text { process to ensure comprehension }\end{array}$ & 1.4 & 2.1 & 8 & 29.4 & 59.1 \\
\hline 8 & $\begin{array}{l}\text { Permits students' objections regarding academic } \\
\text { issues without authoritarian prejudice or intolerance }\end{array}$ & 1.2 & 3.3 & 10.4 & 28.7 & 56.4 \\
\hline 9 & $\begin{array}{l}\text { Does not make negative comments when students } \\
\text { make unsuccessful observations/inconsiderate } \\
\text { remarks }\end{array}$ & 9.6 & 6.3 & 7.1 & 18.8 & 58.2 \\
\hline 10 & $\begin{array}{l}\text { Thoroughly assesses every learning action of the } \\
\text { students and keeps them continuously informed }\end{array}$ & 30.3 & 21.7 & 22.9 & 15.3 & 9.8 \\
\hline 11 & $\begin{array}{l}\text { Tests the academic performance of students } \\
\text { through very frequent written examinations }\end{array}$ & 44.6 & 24.9 & 19.7 & 7.2 & 3.6 \\
\hline 12 & $\begin{array}{l}\text { Provides objective assessment based on written and } \\
\text { oral academic performance without taking into } \\
\text { consideration a student's overall behaviour or } \\
\text { effort }\end{array}$ & 38 & 21.7 & 23.2 & 10.6 & 6.5 \\
\hline 13 & $\begin{array}{l}\text { Reprimands and admonishes the repeatedly } \\
\text { unprepared and indifferent students }\end{array}$ & 24.9 & 29 & 30.8 & 11.5 & 3.8 \\
\hline 14 & $\begin{array}{l}\text { Invites and informs the parents of the repeatedly } \\
\text { unprepared and indifferent students }\end{array}$ & 19.1 & 23.3 & 18.8 & 34.3 & 4.5 \\
\hline 15 & $\begin{array}{l}\text { Lets students discover knowledge by themselves } \\
\text { during homework, through their involvement in } \\
\text { unknown learning situations }\end{array}$ & 20.9 & 33.5 & 29 & 11.5 & 5.1 \\
\hline 16 & Dismisses the class right after the bell has rung & 3.3 & 8.6 & 13.8 & 18.1 & 56.2 \\
\hline
\end{tabular}

Table 1 presents high school students' degree of consent to items referring to teacher features/actions/attitudes which are considered to be linked to the display of a teacher's didactic power. According to data, the majority of the respondents reported that teachers 'much' to 'very much should have profound knowledge of the subject matter they teach $(92.3 \%)$, provide students with frequent feedback to ensure that students develop a good comprehension of the same subject matter (88.5\%), permit students' objections to academic issues without displaying prejudice/intolerance $(85.1 \%)$, and use simple/intelligible language when teaching $(83.7 \%)$. In addition, participants remarked that teachers 'much' to 'very much should implement group work and help students carry out learning projects $(82.4 \%)$, utilize learner-centred teaching strategies to facilitate active participation of the students in the learning procedure (79.5\%), and provide examples and paradigms to simplify 
obscure/difficult learning elements (78.9\%). Furthermore, they reported that teachers 'much' to 'very much should check students' prior knowledge before providing new information in order to facilitate the learning process of scaffolding (i.e., linking new knowledge to knowledge already acquired) (78.9\%), avoid negative comments when students make unsuccessful observations or inconsiderate remarks (77\%), and dismiss the class right after the bell has rung $(74.3 \%)$.

On the other hand, the majority of the participants displayed a negative attitude towards assessment procedures: from 'not at all' to 'slightly' they accept their teacher to test their academic performance through very frequent written examinations (69.5\%), provide objective assessment based on written and oral academic performance without taking into consideration the student's overall behaviour or effort (59.7\%), and let students discover knowledge by themselves during homework, through their involvement in unknown learning situations (54.4\%). They also reported that from 'not at all' to 'slightly' they accept their teacher to reprimand/admonish continuously the repeatedly unprepared and indifferent students $(53.9 \%)$ and assess pedantically every learning action of the students (52\%). Finally, from 'moderately' to 'much' students wanted their teacher to invite and inform the parents of the repeatedly unprepared and indifferent students (53.1\%).

Table 2. Students' responses (in percentages) to the questions looking at the barriers of teachers' legitimate power

\begin{tabular}{|c|c|c|c|c|c|c|}
\hline & $\begin{array}{l}\text { Degree of consent to the following teacher's } \\
\text { attitudes/actions regarding teacher's legitimate } \\
\text { power. } \\
\text { I consent to the teacher when s/he: }\end{array}$ & $\begin{array}{l}\bar{\Xi} \\
\stackrel{\pi}{\pi} \\
0 \\
\\
Z\end{array}$ & $\begin{array}{l}\vec{\lambda} \\
\stackrel{\vec{E}}{.00} \\
\stackrel{.00}{\omega}\end{array}$ & $\begin{array}{l}\frac{\lambda}{0} \\
\frac{\vec{\pi}}{\bar{d}} \\
\frac{0}{2} \\
\sum\end{array}$ & $\stackrel{\tilde{ల}}{\stackrel{\Sigma}{\Sigma}}$ & 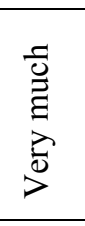 \\
\hline 17 & $\begin{array}{l}\text { Asserts him-/herself through his/her personality instead } \\
\text { of using rules }\end{array}$ & 2.6 & 4.9 & 16 & 32.2 & 44.3 \\
\hline 18 & $\begin{array}{l}\text { Implements flexible behavioural strategies through } \\
\text { interaction and cooperative procedures }\end{array}$ & 1.6 & 5.4 & 24.3 & 41.7 & 27 \\
\hline 19 & $\begin{array}{l}\text { Repeats behaviour rules, checks/ensures continuously } \\
\text { their implementation, repeatedly rewards or admonishes }\end{array}$ & 32.8 & 29.2 & 13 & 15.3 & 9.7 \\
\hline 20 & $\begin{array}{l}\text { Severely reprimands recalcitrant students in cases of } \\
\text { talking out of turn, indecent gestures/words, provocative } \\
\text { behaviour, without however expelling them from the } \\
\text { class }\end{array}$ & 5.7 & 31.4 & 39.6 & 12.6 & 10.7 \\
\hline 21 & $\begin{array}{l}\text { Sets up strict rules and punishments to prevent negative } \\
\text { behaviour }\end{array}$ & 23.8 & 32.7 & 15.1 & 12.7 & 15.7 \\
\hline 22 & $\begin{array}{l}\text { Takes into account current situation/circumstances } \\
\text { when admonishing students }\end{array}$ & 3.2 & 5.9 & 28.6 & 36.5 & 25.8 \\
\hline 23 & $\begin{array}{l}\text { Sends students on errands (e.g. to fetch/carry scientific } \\
\text { instruments/ chalks/teacher's bag, to clean classroom's } \\
\text { desks/blackboard) }\end{array}$ & 37.2 & 20.1 & 18.5 & 11.2 & 13 \\
\hline 24 & Criticizes students for improper dress & 73.2 & 12.5 & 8 & 4.2 & 2.1 \\
\hline 25 & $\begin{array}{l}\text { Prohibits students from chewing gum, wearing } \\
\text { hat/gloves during lesson/sitting in a relaxed stance in } \\
\text { the classroom }\end{array}$ & 14 & 25.6 & 25.4 & 20 & 15 \\
\hline 26 & $\begin{array}{l}\text { Criticizes students for their social out-of-school choices } \\
\text { (e.g. relationships, entertainment) }\end{array}$ & 37.4 & 17.9 & 14.9 & 11.4 & 18.4 \\
\hline
\end{tabular}

Table 2 presents high school students' degree of consent to items referring to teacher features/actions/attitudes which are considered to be linked to the display of the teacher's legitimate power. According to data, the majority of the respondents reported that teachers 'much' to 'very much should assert themselves through their personality instead of using rules (76.5\%), implement flexible behavioural strategies through interaction and cooperative procedures (68.7\%), and take into account current situation/circumstances when admonishing students $(62.3 \%)$. However, the majority of the respondents reported that teachers 'not at all' to 'slightly' should criticize students for improper dress (85.7\%), repeat behaviour rules, check/ensure continuously their implementation, and repeatedly reward or admonish (62\%), send students on errands (e.g. to fetch/carry 
scientific instruments/chalks/teacher's bag, to clean classroom's desks/blackboard) (57.3\%), set strict rules and punishments to prevent negative behaviour $(56.5 \%)$, and criticize students for their social out-of-school choices, such as their relationships or personal entertainment preferences $(55.3 \%)$. The majority of the participants reported that teachers from 'slightly' to 'moderately' should severely reprimand recalcitrant students in cases of talking out of turn, indecent gestures/words, provocative behaviour, without however expelling them from the class $(71 \%)$ and prohibit students from violating the so-called etiquette rules, namely chewing gum, wearing hat/gloves during a lesson, or sitting in a relaxed stance in the classroom $(51 \%)$.

Table 3. Students' reactions (in percentages), in cases of abuse of their teachers' power

\begin{tabular}{|c|c|c|c|c|c|c|}
\hline & $\begin{array}{l}\text { Degree of consent to the following student's } \\
\text { attitudes/reactions }\end{array}$ & 峁 & 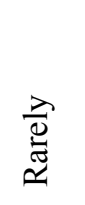 & 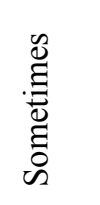 & $\underbrace{\tilde{\Xi}}_{0}$ & $\begin{array}{l}\text { 导 } \\
\stackrel{0}{0} \\
\stackrel{0}{0} \\
>\end{array}$ \\
\hline 27 & $\begin{array}{l}\text { Disregard the teacher's warning/advice, keep on doing } \\
\text { whatever s/he thinks right }\end{array}$ & 20.3 & 34 & 30.5 & 10.2 & 5 \\
\hline 28 & $\begin{array}{l}\text { Obey without objections the teacher's demands, no matter } \\
\text { whether excessive or unfair, through fear of negative } \\
\text { consequences }\end{array}$ & 22.4 & 36 & 11.9 & 20.3 & 9.4 \\
\hline 29 & $\begin{array}{l}\text { Obey a teacher's demands, no matter whether excessive or } \\
\text { unfair, but later discuss personally with the teacher to clear } \\
\text { up a misunderstanding }\end{array}$ & 14.6 & 29.7 & 30.3 & 17.2 & 8.2 \\
\hline 30 & $\begin{array}{l}\text { Expostulate mildly in the classroom about a teacher's } \\
\text { unfairness }\end{array}$ & 6.4 & 15 & 31.6 & 29.6 & 17.4 \\
\hline 31 & $\begin{array}{l}\text { Talk back to the teacher, without taking into account } \\
\text { possible consequences, when s/he behaves/judges unfairly }\end{array}$ & 33.5 & 26.7 & 22.4 & 10.9 & 6.5 \\
\hline 32 & $\begin{array}{l}\text { Discuss with parents on how to handle personally a } \\
\text { misunderstanding with the teacher }\end{array}$ & 10.7 & 17.3 & 28.1 & 23.3 & 20.6 \\
\hline 33 & $\begin{array}{l}\text { Ask parents to meet the teacher and clear up } \\
\text { misunderstandings, on behalf of the student }\end{array}$ & 29.5 & 28.2 & 23.9 & 12.1 & 6.3 \\
\hline 34 & $\begin{array}{l}\text { Ask parents to meet the school principal and discuss } \\
\text { teacher-student misunderstanding }\end{array}$ & 44.3 & 26.5 & 16.4 & 8.6 & 4.2 \\
\hline 35 & Discuss with classmates to decide best reaction & 7.3 & 12.7 & 21.2 & 29.6 & 29.2 \\
\hline 36 & Meet personally the school principal to mediate a settlement & 37.5 & 30.9 & 20.6 & 6.5 & 4.5 \\
\hline
\end{tabular}

Table 3 presents high school students' degree of consent to items referring to student reactions to the abuse of their teacher's power. According to the data, the majority of the respondents 'never' to 'rarely' ask parents to meet the school principal and discuss teacher-student misunderstandings $(70.8 \%)$, meet personally the school principal to mediate a settlement $(68.4 \%)$, and talk back to the teacher, without taking into account possible consequences, when the teacher behaves unfairly $(60.2 \%)$. Furthermore, the majority of the participants reported that they 'never' to 'rarely' obey without objections the teacher's demands, no matter whether excessive or unfair, because of fear of negative consequences (58.4\%), ask parents to meet the teacher and clear up a misunderstanding (57.7\%), and disregard teachers' warning/advice and continue doing whatever they think right (54.3\%). Finally, the majority of the respondents reported that 'often' to 'very often' discuss with classmates to decide the best reaction to a teacher's abuse of power (58.8\%), 'sometimes' to 'often' expostulate mildly in the classroom about a teacher's unfairness $(61.2 \%)$ and discuss with parents on how to handle a misunderstanding with the teacher (51.4\%), while 'rarely' to 'sometimes' obey a teacher's demands, no matter whether excessive or unfair, but later discuss with the teacher to clear up a misunderstanding $(60 \%)$.

\subsubsection{Factor Analysis}

Of the above mentioned 36 variables, 29 were taken into consideration, related in level of significance $\alpha=1 \%$ to the beliefs of 1076 high school students regarding their perceptions of the power of the teacher in the classroom (chi-square independence tests were performed). These 29 items were as follows: 


\section{The teacher:}

[1] Has profound content-based knowledge of the subject

[2] Checks students' prior knowledge before providing new information

[3] Utilizes simple and intelligible language when teaching

[4] Provides examples and paradigms to simplify obscure terms/notions/facts

[5] Utilizes learner-centred teaching strategies to facilitate students' active participation in the learning procedure

[6] Prompts students to work in groups and carry out learning projects

[7] Provides frequent feedback during teaching process to ensure comprehension

[8] Permits students' objections regarding academic issues without authoritarian prejudice or intolerance

[9] Asserts him-/herself through his/her personality instead of using rules

[10] Implements flexible behavioural strategies through interaction and cooperative procedures

[11] Thoroughly assesses every learning action of the students and keeps them continuously informed

[12] Lets students discover knowledge by themselves during homework, through their involvement in unknown learning situations

[13] Tests the academic performance of students through very frequent written examinations

[14] Provides objective assessment based on written and oral academic performance without taking into consideration a student's overall behaviour or effort

[15] Sets up strict rules and punishments to prevent negative behaviour

[16] Severely reprimands recalcitrant students in cases of talking out of turn, indecent gestures/words, provocative behaviour, without however expelling them out of class

[17] Invites and informs the parents of the repeatedly unprepared and indifferent students

[18] Repeats behaviour rules, checks/ensures continuously their implementation, repeatedly rewards or admonishes

[19] Sends students on errands (e.g. to fetch/carry scientific instruments/ chalks/teacher's bag, to clean classroom's desks/blackboard)

[20] Criticizes students for improper dress

[21] Criticizes students for their social out-of-school choices (e.g. relationships, entertainment) The student:

[22] Expostulates mildly in the classroom about teacher's unfairness

[23] Talks back to the teacher, without taking into account possible consequences, when s/he behaves/judges unfairly

[24] Obeys without objections to teacher's demands, no matter whether excessive or unfair, through fear of negative consequences

[25] Discusses with parents on how to handle personally a misunderstanding with the teacher

[26] Asks parents to meet the teacher and clear up a misunderstanding, on behalf of the student

[27] Asks parents to meet the school principal and discusses teacher-student misunderstanding

[28] Discusses with classmates to decide best reaction

[29] Meets personally the school principal to mediate a settlement. 
Table 4. KMO and Bartlett's Test of sphericity

\begin{tabular}{lll}
\hline \multicolumn{2}{l}{ Kaiser-Meyer-Olkin Measure of Sampling Adequacy } & 0.806 \\
\hline Bartlett's Test of Sphericity & Approx. chi-square & 4865.03 \\
& Df & 406 \\
& Sig. & 0.000 \\
\hline
\end{tabular}

Applying factor analysis, we attempted to ascertain the main factors that affect high school students' perceptions of their teacher's power. According table 4, the value 0.806 of the Kaiser-Meyer-Olkin measure for sampling adequacy as an indicator of comparison in the observed values of correlation coefficients to the partial correlation coefficients implied factor analysis of variables was acceptable as a technique for analysing the data (Cattell, 1978; Howitt \& Cramer, 2008). In addition, Bartlett's test of sphericity showed high statistical significance of the statistic $\chi^{2}$ (zero $p$-value), rejecting the hypothesis that the correlation matrix is an identity one and, consequently, factor analysis was adequate.

Table 5. Factor Analysis results

\begin{tabular}{|c|c|c|c|c|c|c|c|c|c|c|c|}
\hline \multirow{3}{*}{ Variables } & & \multicolumn{10}{|c|}{ Rotated Component Matrix } \\
\hline & & \multicolumn{10}{|c|}{ Component } \\
\hline & & 1 & 2 & 3 & 4 & 5 & 6 & 7 & 8 & 9 & Communalities \\
\hline [1] & & 0.649 & 0.022 & -0.012 & -0.197 & 0.040 & -0.036 & -0.100 & -0.117 & 0.174 & 0.518 \\
\hline [2] & & 0.519 & 0.035 & 0.035 & 0.097 & -0.251 & 0.033 & -0.016 & 0.031 & 0.276 & 0.423 \\
\hline [3] & & 0.513 & -0.108 & 0.052 & -0.012 & -0.201 & 0.114 & 0.147 & -0.199 & -0.169 & 0.420 \\
\hline [4] & & 0.557 & 0.077 & -0.044 & -0.022 & 0.032 & -0.089 & 0.073 & 0.137 & -0.280 & 0.430 \\
\hline [5] & & 0.506 & 0.064 & -0.038 & -0.040 & 0.273 & 0.234 & -0.368 & 0.163 & 0.021 & 0.555 \\
\hline [6] & & 0.592 & -0.095 & -0.061 & 0.040 & 0.032 & 0.254 & -0.152 & 0.056 & -0.195 & 0.495 \\
\hline [7] & & 0.658 & 0.005 & -0.010 & -0.165 & -0.002 & -0.073 & -0.020 & -0.091 & 0.000 & 0.474 \\
\hline [8] & & 0.591 & -0.146 & 0.002 & -0.098 & -0.089 & 0.112 & 0.135 & -0.094 & -0.071 & 0.433 \\
\hline [9] & & 0.474 & -0.095 & 0.198 & -0.112 & -0.269 & 0.250 & -0.029 & 0.120 & 0.181 & 0.468 \\
\hline [10] & & 0.562 & -0.168 & 0.200 & 0.057 & -0.129 & 0.067 & 0.087 & 0.022 & -0.003 & 0.416 \\
\hline [11] & & -0.080 & -0.027 & 0.201 & 0.027 & 0.650 & 0.044 & 0.024 & -0.150 & -0.002 & 0.496 \\
\hline [12] & & -0.043 & 0.131 & 0.105 & 0.209 & 0.554 & 0.020 & -0.016 & 0.228 & 0.007 & 0.434 \\
\hline [13] & & -0.169 & 0.120 & 0.199 & 0.174 & 0.584 & -0.116 & 0.070 & -0.131 & 0.170 & 0.519 \\
\hline [14] & & -0.041 & 0.051 & 0.064 & 0.207 & 0.118 & -0.154 & 0.143 & -0.051 & 0.728 & 0.642 \\
\hline [15] & & 0.002 & 0.124 & 0.591 & -0.108 & 0.122 & 0.067 & -0.021 & -0.030 & 0.061 & 0.401 \\
\hline [16] & & 0.116 & 0.024 & 0.737 & -0.021 & 0.119 & -0.038 & -0.134 & 0.069 & -0.072 & 0.601 \\
\hline [17] & & -0.020 & 0.034 & 0.628 & 0.173 & 0.153 & 0.087 & -0.051 & 0.025 & 0.070 & 0.464 \\
\hline [18] & & 0.106 & 0.117 & 0.478 & 0.247 & -0.046 & -0.153 & 0.106 & -0.199 & -0.461 & 0.603 \\
\hline [19] & & -0.093 & 0.013 & 0.068 & 0.190 & -0.098 & 0.044 & 0.103 & 0.660 & 0.079 & 0.514 \\
\hline [20] & & -0.100 & 0.080 & 0.040 & 0.820 & 0.096 & 0.039 & -0.065 & -0.025 & 0.051 & 0.709 \\
\hline [21] & & -0.169 & 0.159 & 0.012 & 0.700 & 0.243 & -0.066 & 0.065 & 0.048 & 0.109 & 0.625 \\
\hline [22] & & 0.115 & -0.019 & -0.037 & -0.107 & 0.006 & 0.235 & 0.745 & 0.085 & 0.061 & 0.647 \\
\hline [23] & & -0.045 & 0.107 & -0.191 & 0.114 & 0.096 & -0.089 & 0.651 & 0.245 & 0.043 & 0.567 \\
\hline [24] & & -0.006 & 0.129 & 0.050 & 0.200 & -0.019 & 0.107 & -0.153 & -0.662 & 0.111 & 0.545 \\
\hline [25] & & 0.100 & 0.216 & 0.238 & 0.043 & -0.156 & 0.653 & 0.026 & 0.117 & -0.111 & 0.593 \\
\hline [26] & & -0.051 & 0.793 & 0.112 & 0.010 & 0.053 & 0.119 & -0.047 & -0.112 & 0.090 & 0.684 \\
\hline [27] & & -0.119 & 0.838 & 0.081 & 0.059 & 0.066 & 0.021 & -0.012 & -0.058 & 0.046 & 0.736 \\
\hline [28] & & 0.134 & -0.058 & -0.071 & -0.040 & 0.095 & 0.719 & 0.095 & -0.162 & -0.008 & 0.590 \\
\hline [29] & & -0.068 & 0.593 & 0.040 & 0.267 & 0.066 & -0.083 & 0.177 & 0.107 & -0.170 & 0.512 \\
\hline $\begin{array}{l}\text { Percentage } \\
\text { of total } \\
\text { variance } \\
\text { explained }\end{array}$ & $\begin{array}{l}\text { Rotation } \\
\text { sums of } \\
\text { squared } \\
\text { loadings }\end{array}$ & 11.615 & 6.720 & 6.307 & 5.748 & 5.345 & 4.662 & 4.639 & 4.438 & 4.017 & \\
\hline
\end{tabular}

Note: Communality or common factor variance: total variance of each variable explained by common factors

We applied factor analysis to the group of 29 previously mentioned variables. Since performance of principal component analysis (PCA) from the first nine components explained $53.493 \%$ of the total variance and that only the first nine components had eigenvalues greater than 1, we proceeded by using PCA with Varimax rotation extraction method in nine components. The results are presented in table 5. 


\subsubsection{Comments on the Factor Analysis Results}

Based on the results of the factor analysis, the nine main factors were as follows:

Factor 1: Teacher's 'know-what' and 'know-how'. Variables with significant positive influence among them and with the Highest Factor Loadings [VHFL]: [1], [2], [3], [4], [5], [6], [7], [8], [9] and [10]. According to the results, the high school teacher's power in the classroom can be acceptably exerted when s/he is an expert in the subject being taught and, at the same time, s/he can help students assimilate the knowledge provided during the teaching/learning process.

Factor 2: Students' reaction through mediators. [VHFL]: [26], [27] and [29]. According to the results, in cases of teacher misuse of power, high school students avoid personal conflict with the teacher and rarely prefer their parents or the school principal to intervene/mediate and clear up any possible misunderstanding.

Factor 3: Imposing rules and infliction of penalties. [VHFL]: [15], [16], [17] and [18]. According to the results, teachers exercise their legitimate power and coerce students into improving academic performance and interpersonal behaviour through the enforcement of rules, the infliction of penalties and by informing the parents.

Factor 4: Unacceptable criticism. [VHFL]: [20] and [21]. According to the results, criticism by teachers of student in-school dress, entertainment, relationships or other social out-of-school choices is not accepted.

Factor 5: Over-assessment and homework overloading. [VHFL]: [11], [12] and [13]. According to the results, teachers often exert their power through the involvement of students in multiple assessment procedures and, at the same time, through the designation of challenging learning tasks.

Factor 6: Getting advice. [VHFL]: [25] and [28]. According to the results, high school students often prefer to address a misunderstanding personally with the teacher, after seeking relevant advice from their parents or classmates/friends.

Factor 7: Immediate objection/reaction. [VHFL]: [22] and [23]. According to the results, high school students often react immediately to their teacher's abuse of power - politely when possible consequences are taken into consideration, or in a less respectful way when the students disregard the negative consequences of their own offensive stance.

Factor 8: Students' obedience to demands. [VHFL]: [19] and [24]. According to the results, high school students often obey passively their teachers' demands due to the fear of possible consequences.

Factor 9: Academic performance assessment. [VHFL]: [14]. According to the results, teachers often exert their power on the students through the exclusive assessment of their cognitive achievements, while student effort, potential, personal traits or circumstances are not taken into consideration.

\section{Conclusions and Discussion}

The present study examined, firstly, the perceptions of Greek high school students of their teachers' didactic power. According to the results, Greek high school students, like their international counterparts (Richmond \& McCroskey, 1984; Turman \& Schrodt, 2006), highly respect expert teachers, probably due to the feeling of safety that such educators inspire in their students (Kearney, Plax, \& Allen, 2002). Professional expertise is also highly esteemed by Greek students due to the significant contribution of effective teachers to students' admission in University courses, which constitutes an overriding objective for almost all Greek families since it increases professional opportunities for young people and facilitates their further social and economic development (Koustourakis,2007; Traianou, 2009).

However, according to participants' views shown in table 1, a teacher's didactic power is not based only on his/her profound content-knowledge, but also on the use of tactics which facilitate effective dissemination of knowledge by the teacher and effective assimilation by the students. More specifically, as factor 1 indicates, didactic power is also exerted when the teacher smoothes over students' learning difficulties, encourages interpersonal interaction and participation, respects students' efforts, and assesses learning performance in a way which does not increase stress, frustration or disappointment in the students. The notion of didactic power acquires, thus, more democratic content and connotations which seem to better respond to the social requirements of a more learner-centred educational era (Noyes, 2005). When such a learner-centred setting has been established in the classroom, students seem to be more willing to consent to significant extension of the boundaries of the teacher's didactic power, as long as supportive, trustful and cooperative student-teacher relationships have also been established, as Meece, Herman, and McCombs (2003) and Murray and Malmgren (2005) have already confirmed. 
On the other hand, the boundaries of a teacher's didactic power seem to be restricted by the students, as factor 9 indicates, in cases where the teacher shows disdain for their learning effort and overall behaviour and bases his/her opinion of the students exclusively on their academic performance. In such cases, students seem to resist the exertion of the teacher's didactic power, especially if the teacher assesses them on unfamiliar topics, sets written tests very frequently or assigns highly demanding homework, as factor 5 indicates and Yariv (2009) has already shown. Furthermore, the attitude Greek teachers have towards their students just after the bell has rung is considered to reflect the teacher's unacceptable will to exert their power over the students by depriving them of their legitimate right to rest during the recess. Blatchford and Sumpner (1998) have shown that in such cases teachers believe that they exert their didactic power (because they try to complete their teaching unit, since incompletion would potentially result in an ineffective learning process), while the students believe that the teachers exert their legitimate power (since they violate an official rule) and provide evidence, at the same time, of their didactic power's ineffectiveness (because they are regarded as unable to plan their lessons properly and ensure completion of tasks in the time provided).

The present study examined, secondly, the perceptions of Greek high school students of their teachers' legitimate power. According to the results, Greek high school students regard teachers' criticism regarding attire and out-of-school entertainment as completely inappropriate (factor 4), probably because through his/her personal dress choices a student demonstrates how s/he wants to be seen/perceived by others, while through personally-chosen ways of entertainment a student satisfies and integrates the affective and social domains of his/her personality, given that school is regarded as focused exclusively on cognitive development. It is also worth mentioning that Greek students, like their international counterparts (Murray \& Thompson, 1985; Smentana \& Bitz, 1996), seem, in many cases, to include even their academic performance in their personal matters, and this probably explains why they do not willingly want their parents to be invited to school and be informed about their behaviour or academic performance. Yariv (2009) and Laupa and Tse (2005) have confirmed that adolescent students tend to consider that teacher interference in personal preferences and choices, or in whatever is considered to be personal, is illegitimate and unacceptable, and this probably explains why these students violate more vehemently the boundaries of a teacher's legitimate power firstly in order to reject his/her undesirable indiscreet interventions and secondly to establish their personal boundaries which are based on their need to be respected and accepted as individuals. In fact, van Manen (1991) has confirmed that students react reciprocally to their teacher's attitude and behaviour. They demand their teachers to implement tactful communicative and behavioural strategies that are unobtrusive and create a distance from any manipulative or indiscreet interpersonal relationship between teacher and student. In any case, as soon as they feel respected they show respect in recompense.

Furthermore, as regards a teacher's legitimate power to set up behavioural rules and apply them, Greek students seem to hold a negative attitude, in contrast to Malone and Tietjens's (2000) report. According to the latter, clear specification and justification of behavioural rules at the beginning of the school year and repetitive reminders during the course of the year facilitates and ensures student cooperation and commitment. In contrast, Greek students are only slightly willing to accept their teachers' implementation of behavioural rules within the school setting (factor 3). They are also rather sceptical whenever teachers severely reprimand recalcitrant and unruly students to prevent negative learning and behavioural outcomes, although Yariv (2009) has reported that this particular right of the teacher is situated in the "inner concentric circle" which includes the most established and legitimate teaching tactics, duties, and rights. To explain these differentiations one should take into account that the main objectives of Greek education, despite successive reforms, remain exclusively academic and are focused on the cognitive development of students through the dissemination of large chunks of knowledge during a teaching process where quantity takes priority over quality (Ifanti, 2007; Traianou, 2009). It is probable that Greek students, being involved in such an academic, almost impersonal, system which pays no attention to their affective, social and behavioural development and wellbeing, are reciprocally unwilling to cede such rights to the representatives of this system, namely the teachers. In addition, severe rebuking, repeated reminders of rules and punishments, and continuous criticism are considered to impel students to underestimate the pedagogical worth of a teacher's legitimate power (Banfield, Richmond, \& McCroskey, 2006; Tollesfon, 2000). Finally, as Zhang (2007) has shown, the exertion of the teacher's legitimate power in such ways produces substantial negative effects on student motivation to learn while, at the same time, it makes students resort to undesirable verbal and non-verbal techniques in order to limit the excessive use of their teacher's legitimate power (Golish \& Olson, 2000). In fact, as Goodman (2010) has noticed, the unwise use of the teacher's legitimate power violates the students' personal boundaries and gives rise to an excessive exertion of counterbalancing student power which is regarded by them as an antidote to the alienation that the teacher has first tried to establish in his/her relationship with the students. 
The present study examined, thirdly, the attitudes and reactions of Greek high school students in cases of abuse of their teachers' didactic and legitimate power. Factor 8 indicates that a significant percentage (though not the majority) of Greek students prefer not to react actively to a teacher's excessive or unfair demands. Unresponsiveness, however, should not be perceived as indifference. The majority of Greek students are devoted to their studies, since, as abovementioned, high academic performance in school subjects and the corresponding grades provided by the teachers, are considered to ensure student admission to the University and subsequent social and professional development. It is rather apparent that Greek students exhibit possible negative feelings and evade active reactions in order to ingratiate themselves with the teacher and prevent a decrease in their grades which could be used by the teacher as retaliation for student disobedience. This fear could also explain why, as factor 7 indicates, why Greek students rarely talk back to teachers who are regarded as unfair, while, on the contrary, mild and polite reactions are considered to be more effective and preferable to offensive or aggressive protest, a common attitude confirmed through international reports (Johnson \& Ford, 1996; Kearney, Plax, \& Allen, 2002; Kearney, Plax, \& Burroughs, 1991).

Greek students also seem rather reluctant to discuss privately with their teachers any possible complaints. Golish (1999) has reported that this attitude is further exacerbated when students feel affronted by their teacher's abuse of power and are afraid that the teacher will try to ensure student compliance through so-called 'private persuasion', where the student, when alone with the teacher, is unable to gain public support from his/her classmates. It is also rather apparent, as factor 6 indicates, that in cases of a teacher's abuse of power, Greek students tend to address the problem on their own, having, of course, previously discussed it in confidence with their parents or best friends, as their international counterparts would do (Berndt, 1999; Golish, 1999; Hurter, 1996; Sidelinger, Bolen, Frisby, \& McMullen, 2011).

However, as factor 2 indicates, although Greek high school students tend to ask their parents for advice, they do not permit them to get involved in their school life and meet the teacher on their behalf. According to the results, the most undesirable choice, in fact, is to ask for the school principal's support, as has already been confirmed by Yariv (2009). It is probable that the school principal is regarded by the students as an integral part of the educational system and in a sense $\mathrm{s} / \mathrm{he}$ is expected to be, in advance, prejudiced in favour of the teacher. On the other hand, adolescent students probably try to protect their independence and autonomy by defining their own boundaries against adult power which seems to be represented and exerted by teachers, school principals and, even, their own parents, as former research has confirmed (Laupa \& Tse, 2005; Murray \& Thompson, 1985; Smentana \& Bitz, 1996).

The present study shows that teachers should assert themselves through their personality and not through the use of rules. It also shows that teachers have to work systematically and consciously in order to gradually develop and establish creative, trustful, and meaningful communication with their students. It seems that the era of a teacher's didactic or legitimate power which is not tightly linked to the integrated personality of the teacher is irrevocably over. Since today adolescents seem to have fully realized their potential power in the classroom and, also, understood the relational and mutual nature of the learning process, teachers should be encouraged, as Mottet et al. $(2004,37)$ have put it "to acknowledge student influence and to use this influence in ways that will help them meet both their students' and their own instructional and interpersonal needs".

\section{References}

Alahiotis, S., \& Karatzia, E. (2006). Effective curriculum policy and cross-curricularity: Analysis of the new curriculum design of the Hellenic Pedagogical Institute. Pedagogy, Culture and Society, 14(2), 119-47. http://dx.doi.org/10.1080/02619768.2011.654332

Banfield, R. S., Richmond, V. P., \& McCroskey, J. C. (2006). The effect of teacher misbehaviors on teacher credibility and affect for the teacher. Communication Education, 55, 63-72. http://dx.doi.org/10.1080/03634520500343400

Baringer, D. K., \& McCroskey, J. C. (2000). Immediacy in the classroom: Student immediacy. Communication Education, 49(2), 178-186. http://dx.doi.org/10.1080/03634520009379204

Berndt, J. T. (1999). Friends' influence on students' adjustment to school. Educational Psychologist, 34, 15-28. http://dx.doi.org/10.1207/s15326985ep3401_2

Blatchford, P., \& Sumpner, C. (1998). What Do We Know about Breaktime? Results from a National Survey of Breaktime and Lunchtime in Primary and Secondary Schools. British Educational Research Journal, 24, 79-94. Retrieved from http://www.jstor.org/stable/1501757 
Cattell, R. B. (1978). The scientific use of factor analysis in behavioral and life sciences. New York: Plenum Press.

Coleman, L., \& Zajicek-Coleman, E. (1984). Adolescents' attitudes to authority. Journal of Adolescence, 7(2), 131-141. http://dx.doi.org/10.1016/0140-1971(84)90004-6

Ellis, K. (2000). Perceived teacher confirmation the development and validation of an instrument and two studies of the relationship to cognitive and affective learning. Human Communication Research, 26(2), 264-291. http://dx.doi.org/10.1111/j.1468-2958.2000.tb00758.x

Franklin, B. M. (1986). Building and American community: The school curriculum and the search for social control. London: Falmer Press.

Gallagher, M. (2008). Foucault, power and participation. International Journal of Children's Rights, 16(3), 395-406. http://dx.doi.org/10.1163/157181808X311222

Golish, D.T., \& Olson, L.N. (2000). Students' use of power in the classroom: An investigation of student power, and teacher immediacy. Communication Quarterly, 48(3), 293-310. http://dx.doi.org/10.1080/01463370009385598

Golish, T. D. (1999). Students' use of compliance gained strategies with graduate teaching assistants: Examining the other end of the power spectrum. Communication Quarterly, 47, 12-32. http://dx.doi.org/10.1080/01463370009385598

Goodman, J. (2010). Student authority: Antidote to alienation. Theory and Research in Education, 8(3), 227-247. http://dx.doi.org/10.1177/1477878510381626

Gregory, A., \& Ripsky, B.M. (2008). Adolescent trust in teachers: Implication for behaviour in the High school classroom. School Psychology Review, 37(3), 337-353. Retrieved from $\mathrm{http}: / /$ www.nasponline.org/publications/spr/index.aspx?vol=37\&issue $=3$

Harjunen, E. (2009). How do teachers view their own pedagogical authority? Teachers and Teaching, 15, 109-129. http://dx.doi.org/10.1080/13540600802661345

Harjunen, E. (2011). Students consent to a teacher's pedagogical authority. Scandinavian Journal of Educational Research, 55(4), 403-424. http://dx.doi.org/10.1080/00313831.2011.587325

Harter, S. (1996). Teacher and classmates influences on scholastic motivation, self-esteem, and level of voice in adolescents. Ed. J. Juvonen and K. R. Wentzel. Social Motivation. Understanding children's school adjustment (pp. 11-43). New York: Cambridge University Press.

Howitt, D., \& Cramer, D. (2008). Introduction to Statistic Psychology. Harlow: Pearson.

Ifanti, A. (2007). Policy and curriculum development in Greece. The case of secondary school curriculum. Pedagogy, Culture and Society, 15, 71-81. http://dx.doi.org/10.1080/14681360601162287

Johnson, C., \& Ford, R. (1996). Dependence power, legitimacy, and tactical choice. Social Psychology Quarterly 59(2), 126-139. Retrieved from http://www.jstor.org/stable/2787047

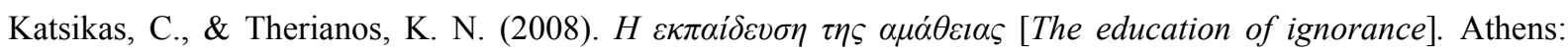
Gutenberg.

Kearney, P., Plax, T. G. Richmond, V. P., \& McCroskey, J. C. (1984). Power in the classroom IV: Alternatives to discipline. In R. N. Bostrom (Ed.). Communication Year Book (Vol. 8, pp. 724-746). Beverly Hills, CA: Sage.

Kearney, P., Plax, T. G., \& Allen, T. H. (2002). Understanding student reactions to teachers who misbehave. In J.L. Chesebro \& J.C. McCroskey (Eds). Communication for Teachers (pp.127-140). Boston: Allyn and Bacon.

Kearney, P., Plax, T. G., \& Burroughs, N. F. (1991). An attributional analysis of college students' resistance decisions. Communication Education, 40(4), 325-342. http://dx.doi.org/10.1080/03634529109378858

Koustourakis, G. (2007). The new educational policy for the reform of the curriculum and the change of school knowledge in the case of Greek compulsory education. International Studies in Sociology of Education, 17, 131-146. http://dx.doi.org/10.1080/09620210701433878

Laupa, M., \& Tse, P. (2005). Authority concepts among children and adolescents in the island of Macao. Social Development, 14(4), 652-663. http://dx.doi.org/10.1111/j.1467-9507.2005.00322.x 
Lee, C. R., Levine, T. R., \& Cambra, R. (1997). Resisting compliance in the multicultural classroom. Communication Education, 46, 29-43. http://dx.doi.org/10.1080/03634529709379071

Levine, T. R., \& Wheeless, L. R. (1997). Situational intimacy as a predictor of compliance-gaining tactic selection. Communication Research Reports, $14(2), \quad$ 132-144. http://dx.doi.org/10.1080/08824099709388655

Malone, B. G., \& Tietjens, C. L. (2000). Re-examination of classroom rules: The need for clarity and specified behavior. Special Services in the Schools, 16, 159-70. http://dx.doi.org/10.1300/J008v16n01_11

McCroskey, J. C., \& V. P., Richmond. (1983). Power in the classroom I: Teacher and student perceptions. Communication Education, 32(2), 175-184. http://dx.doi.org/10.1080/03634528309378527

Meece, J. Herman, L., P., \& McCombs, B. L. (2003). Relations of learner-centred teaching practices to adolescents' achievement goals. International Journal of Educational Research, 39(4-5), 457-475. http://dx.doi.org/10.1016/j.ijer.2004.06.009

Metz, M. H. (1978). Classroom and corridors: The crisis of authority in desegregated secondary schools. Berkeley: University of California Press.

Mottet, P. T., Beebe, A. S., Raffeld, C. P., \& Paylset, L. M. (2004). The effects of student verbal and nonverbal responsiveness on teachers' liking of student and willingness to comply with student request. Communication Quarterly, 52, 27-38. http://dx.doi.org/10.1080/01463370409370176

Murray, C., \& Malmgren, K. (2005). Implementing a teacher-student relationship intervention in a high-poverty urban school. Journal of School Psychology, 43(2), 137-152. http://dx.doi.org/ 10.1016/j.jsp.2005.01.003

Murray, C., \& Thompson, F. (1985). The representation of authority: An adolescent view point. Journal of Adolescence, 8(3), 217-229. http://dx.doi.org/ 10.1016/S0140-1971(85)80054-3

Noyes, A. (2005). Pupil voice: purpose, power and the possibilities for democratic schooling. British Educational Research Journal, 31(4), 533-540. http://dx.doi.org/10.1080/01411920500153614

Pace, J. L., \& Hemmings, A. (2007). Understanding authority in the classroom: A review of theory ideology and research. Review of Educational Research, 77, 4-27. http://dx.doi.org/10.3102/0034654309339500

Peters, R. S. (1966). Authority, responsibility, and education. New York: Atherton.

Richmond, V. P., \& McCroskey, J. C. (1984). Power in the classroom II: Power and learning. Communication Education, 33(2), 125-136. http://dx.doi.org/10.1080/03634528609388318

Richmond, V. P., \& Roach, K. D. (1992). Power in the classroom: Seminal studies. In V.P. Richmond \& J.C. McCroskey (Eds). Power in the classroom: Communication, control and concern (pp. 47-66). Hillsdale: Erlbaum.

Sidelinger J. R., Bolen, D. M., Frisby, B. N., \& McMullen, A. L. (2011). When instructors misbehave: An examination of student-to-student connectedness as a mediator in the college classroom. Communication Education, 60(3), 340-361. http://www.informaworld.com/openurl?genre=article\&id=doi:10.1080/03634523.2011.554991

Smetana, G. J., \& Bitz, B. (1996). Adolescents' conceptions of teachers' authority and their relations to rule $\begin{array}{lllll}\text { violations in } & \text { school. Child }\end{array}$ http://dx.doi.org/10.1111/j.1467-8624.1996.tb01788.x

Tinsley, H. E., \& Tinsley, D. J. (1987). Uses of factor analysis in counselling psychology research. Journal of Counselling Psychology, 34(4), 414-424. http://dx.doi.org/ 10.1037/0022-0167.34.4.414

Tollesfon, N. (2000). Classroom applications of cognitive theories of motivation. Educational Psychology Review, 12, 63-83. http://dx.doi.org/1040-726X/00/0300-0063

Traianou, A. (2009). The uncertain character of recent educational reform in Greece. Forum, 51(2), 131-142. www.wwwords.co.uk/FORUM

Turman, D. P., \& Schrodt, P. (2006). Student perceptions of teacher power as a function of perceived teacher confirmation. Communication Education, 55(3), 265-279. http://dx.doi.org/10.1080/03634520600702570

Van Manen, M. (1991). The tact of teaching: The meaning of pedagogical thoughtfulness. New York, Albany: State University of New York Press. 
Yariv, E. (2009). Students' attitudes on the boundaries of teachers' authority. School Psychology International, 30, 92-111. http://dx.doi.org/10.1177/0143034311424660

Zhang, Q. (2007). Teacher misbehaviors as learning demotivators in college classrooms: A cross-cultural investigation in China, Germany, Japan, and the United States. Communication Education, 56(2), 209-227. http://dx.doi.org/10.1080/03634520601110104 